\title{
TGFB1I1 wt Allele
}

National Cancer Institute

\section{Source}

National Cancer Institute. TGFB1/1 wt Allele. NCI Thesaurus. Code C114352.

Human TGFB1I1 wild-type allele is located in the vicinity of 16p11.2 and is approximately $6 \mathrm{~kb}$ in length. This allele, which encodes transforming growth factor beta-1-induced transcript 1 protein, is involved in the modulation of both signaling and nuclear receptordependent gene expression. 